\title{
Küçük Hücreli Prostat Kanseri: Olgu Sunumu
}

\author{
Small Cell Carcinoma of the Prostate: Case Report \\ Ali Murat TATLI', Mükremin UYSAL', Cumhur İbrahim BAŞSONGUR ${ }^{2}$, Deniz ARSLAN', \\ Hasan Şenol COŞKUN ${ }^{1}$ \\ 19Akdeniz Üniversitesi Tıp Fakültesi, İç Hastalıkları AD, Tıbbi Onkoloji, Antalya \\ ${ }^{2}$ Akdeniz Üniversitesi Tıp Fakültesi, Patoloji AD, Antalya
}

Öz

Prostatın küçük hücreli karsinomu oldukça nadir görülür. Klasik prostat adenokarsinomunun tersine klinik seyri agresiftir ve erken tanı konulmazsa prognozu kötüdür. Metastatik hastalıkta bile PSA seviyelerinin normal olması, hormonal tedaviye yanıtsızlık görülmesi ile prostatın küçük hücreli karsinomundan şüphelenmelidir. Burada prostat küçük hücreli karsinom tanısı saptanan 65 yaşında bir olgu sunularak literatür bilgileri gözden geçirilmiştir.

Anahtar Kelimeler: Prostat karsinomu; küçük hücreli karsinom; normal PSA.

\begin{abstract}
Small cell carcinoma of the prostate is extremely rare. In contrast to classical prostatic adenocarcinoma, clinical course is aggressive and unless detected in early stage, the prognosis of this cancer is poor. If in a patient with metastatic disease PSA levels are normal and hormone therapy is non-effective, small cell carcinoma of the prostate should be suspected. Here, a 65-year-old patient with a diagnosis of small cell carcinoma of the prostate is presented and the relevant literature is reviewed.
\end{abstract}

Keywords: Prostate carcinoma; small cell carcinoma; normal PSA. 


\section{Giriş̧}

Prostat küçük hücreli karsinomu nadir görülen ve agresif seyirli bir tümördür. Tüm prostat kanserlerinin \%0.5-2'sini oluşturur (1). İlk olarak 1977 yılında Wenk ve arkadaşları tarafından tanımlanmıştır (2). Prostatın küçük hücreli karsinomları, adenokarsinomlarının aksine erken dönemde sistemik yayılım yapma eğilimindedir. Tedavi uygulanan olgularda 2 yıllık genel sağkalım \%20'lerde iken tedavi alamayan olgularda yaşam süresi son derece kısadır (3). Bu tümörler agresif seyirli olmaları yanında kemoterapi ve radyoterapiye duyarlı, ancak adenokarsinomların aksine hormonal tedaviye yanıtsızdırlar. Burada prostat küçük hücreli kanseri olan kemoterapi ve radyoterapi ile parsiyel yanıt alınan bir olgu sunuldu.

\section{OLGU SUNUMU}

Altmış beş yaşında erkek hasta üroloji kliniğinde 4 yıldır benign prostat hiperplazisi (BPH) tanısıyla medikal tedavi altında takip edilmekteydi. Sekiz aydır idrar yapmada zorlanma ve sol kasık ağrısı şikayeti artış göstermiş ve parmakla rektal muayenede prostat lojunda kitle saptanmıştı. Hastanın prostat spesifik antijen (PSA) düzeyi normaldi. Yapılan biyopside undiferansiye prostat karsinomu tanısı konmuştu (Şekil I). Tanı anında prostat boyutları $5 \times 5 \mathrm{~cm}$ ve prostat sol posterolateral duvarda paran-
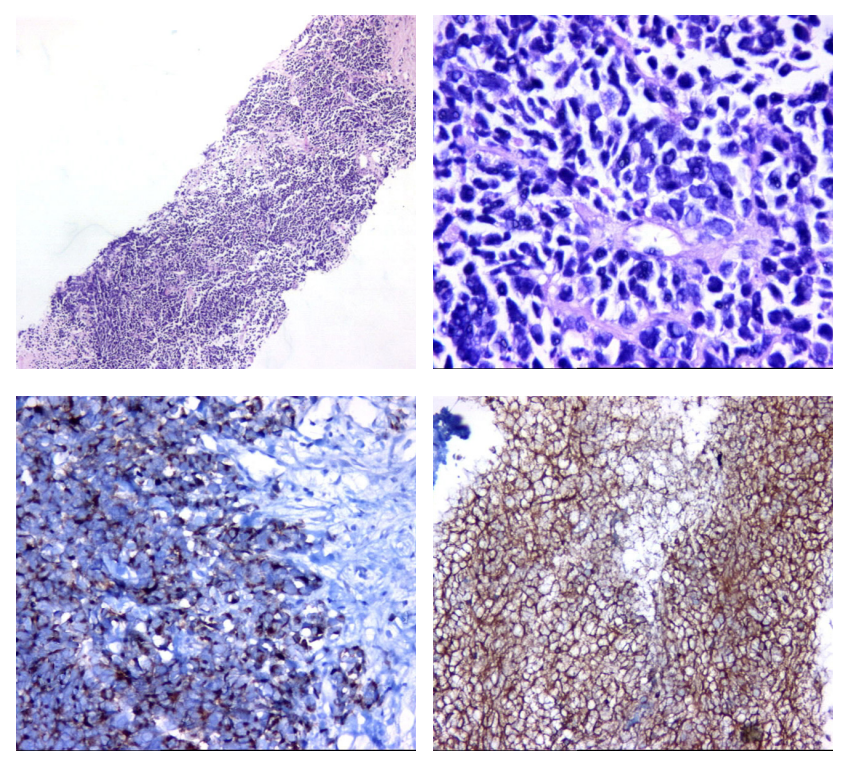

Şekil I: A) Iğne biyopsi örneğinde hiperkromatik nukleuslu dar sitoplazmalı hücrelerden oluşan tümör izlenmekte (HEx40). B) Tümör dokusu içinde rozet yapıları dikkati çekmektedir (HEx400). C) Tümör hücrelerinde immünohistokimyasal yöntem ile uygulanan kromogranin pozitifliği. D) Tümör hücrelerinde immünohistokimyasal yöntem ile uygulanan sinaptofisin pozitifliği. kimden dışarı protrüze, rektum anterior duvar ile yakın komşulukta nodüler yumuşak doku dansitesinde kitle ve bilateral iliak bölgede lenf nodu saptanmıştı. Hastaya bikalutamid $50 \mathrm{mg} /$ gün ve leuprolid 11,25 mg 3 ayda bir başlanmış ve takibe alınmıştı. Üç aylık tedavi sürecinde hastanın klinik olarak progresyon gösterdiği gözlemlenmiş ve $18 \mathrm{~kg}$ kilo kaybı saptanılmıştı. Yapılan radyolojik görüntülemede; prostat boyutu $9 \times 8 \times 5 \mathrm{~cm}$, prostat posterolateralde $5 \times 4,5$ $\mathrm{cm}^{\prime}$ lik kitle ve pelvik bölgede multiple lenfadenopatiler izlenmişti. Hastanın yapılan yeniden değerlendirilmesinde tanının prostatın küçük hücreli karsinomu olduğu belirlendi. Radyolojik evresi T4N1M0 olarak bulundu. ECOG performans skoru 3'tü ve hasta kaşektikti. Hastaya prostatın küçük hücreli karsinomu tanısıyla karboplatin 4 AUC/gün, 1 gün ve etoposid $100 \mathrm{mg} /$ m2, 3 gün her 21 günde bir olmak üzere 2 kür kemoterapi uygulandı. Kemoterapi sonrasında pelvik bölgeye toplam 4000 cGy radyoterapi uygulandı. Radyoterapi sonrası 2 kür daha aynı kemoterapi tekrarlandı. Tedavi sonunda hastanın genel durumu iyileşti (ECOG performans skoru 2) ve kitleye bağlı bası semptomlarının kaybolduğu izlendi. Radyolojik değerlendirmede parsiyel yanıt elde edilmiştir. Hastanın tedavi sonrası takibinin 9. ayında tekrar progresyon olduğu gözlendi. İkinci basamak tedavi olarak ifosfamid ve irinotekan tedavisi başlandı. Tedavi altında 3 ay boyunca stabil hastalık olarak takip edilen hasta tedaviyi tolere etmekte zorlanınca kemoterapi kesilerek takibe alındı. Daha sonra destek tedavide kalınan hastanın takibinin 15 . ayında kaybedilmiştir.

\section{TARTIŞMA}

Bizim ülkemizdeki sıklığı tam olarak bilinmemekle birlikte Amerika Birleşik Devletlerindeki istatistiklere bakıldığında her yıl 238.590 yeni prostat kanseri vakası saptanmış ve her yıl 29.720 kişinin prostat kanserinden öldüğü tespit edilmiştir (4). Prostat kanseri tanısının konulması zor değildir. Ancak prostat kanserinin küçük hücreli tipi çok nadir görüldüğü için ilk tanı anında atlanabilmektedir. Diğer tüm küçük hücreli kanserlerde olduğu gibi prostatın küçük hücreli kanseri de çok agresif seyirli olup lokal evrede saptanamazsa prognozu kötüdür. 
Nitekim bizim vakamızda da ilk tanı anında bir gecikme yaşanmıştır. Prostatın küçük hücreli kanserleri klinik davranışları ile klasik adenokarsinomlardan ayırt edilebilirler. Hastalığın lokal agresif veya metastaz yapması; çoğunlukla visseral organ metastazı ve litik kemik metastazı yapması, PSA düzeyinin normal olması yanında androjen ablasyon tedaviye yanıtsızlığı klinik olarak bir ayrım sağlamada yol gösterebilir. Özelliklede prostat adenokarsinomlarında blastik kemik metastazlarının olmasına karşın küçük hücreli kanserlerde tipik olarak litik kemik metastazların gözlenmesi nedeniyle böyle bir durumda klinisyen histopatolojik tanı konulmadan önce bile şüphelenmelidir (5-7).

Hastaların yaklaşık \%50'si başlangıç tanı anında pür küçük hücreli olup \%25-50'si ise prostat adenokarsinomu ve küçük hücreli karsinom birlikteliği şeklinde gözlenmektedir (8). Hastaların yaklaşık \%25-40'inde ise başlangıç tanısı sadece adenokarsinom iken hormonal tedavi sonrası küçük hücreli karsinom ve adenokarsinom şeklinde kombine tip karsinom olarak nüks etmektedir $(8,9)$.

Prostatın küçük hücreli karsinomu, adenokarsinomlardan farklı olarak tanı anında büyük çoğunluğu semptomatiktir. Sık gözlenen bulgu ve semptomlar ise çoğunlukla obstruktif ve nörolojik komponenetleri içermekle birlikte paraneoplastik sendrom, kemik ağrısı, karın ağrısı, hidronefrozis, hematokezya ve hematüridir. Bizim hastamızda benzer şekilde tanı anında idrar yapmada zorlanma ve sol kasık ağrısı şeklinde ön planda obstruktif semptomlarla müracaat etmiştir.

Ekstrapulmoner küçük hücreli karsinomların nadir görülmesi nedeniyle standart bir tedavi şeması yoktur. Ancak küçük hücreli akciğer kanserindeki deneyimler yol göstericidir. Küçük hücreli karsinomun ana tedavisi kemoterapidir. Sınırlı hastalıkta kemoterapiye radyoterapinin ilave edilmesi lokal kontrolü arttırmaktadır. Ancak ekstrapulmoner hastalıkta kemoterapi sensitivitesi daha düşük olmakla birlikte iyi sonuçlar bildirilmiştir $(10,12)$. Lokal evre hastalıkta kemoterapi ile birlikte radyoterapi uygulaması sonucu kür sağlanabilmektedir (12). Sonuç olarak prostat küçük hücreli karsinomu nadir görülmesi ve prostat adenokarsinomların aksine kötü seyirli olması sebebiyle dikkat çekmektedir. Prostata yerleşen küçük hücreli karsinomlar diğer ekstratorasik küçük hücreli karsinomlar gibi kemoterapi ve radyoterapiye duyarlı, hormonal tedaviye yanıtsızdır. Nüks veya metastaz durumunda PSA seviyesinin artmaması, hormonal tedaviye yanıtsızlık tanı için uyarıcı olmalıdır.

\section{KAYNAKLAR}

1. Helpap B, Köllermann J, Oehler U. Neuroendocrine differentiation in prostatic carcinomas: histogenesis, biology, clinical relevance, and future therapeutical perspectives. Urol Int 1999; 62(3): 133-8.

2. Wenk RE, Bhagavan BS, Levy R, Miller D, Weisburger W: Ectopic ACTH, prostatic oat cell carcinoma, and marked hypernatremia. Cancer 1977;40(2):773-8

3. Oesterling JE, Hauzeur CG, Farrow GM. Small cell anaplastic carcinoma of the prostate: a clinical, pathological and immunohistological study of 27 patients. J Urol 1992;147(3):8047

4. American Cancer Society: Cancer Facts and Figures 2013. Atlanta. Available online: http://www.cancer.org/acs/groups/ content/@epidemiologysurveilance/documents/document/ acspc-036845.pdf. Erişim 13.03.2013.

5. Spiess PE, Pettaway CA, Vakar-Lopez F, et al. Treatment outcomes of small cell carcinoma of the prostate: a singlecenter study. Cancer 2007;110(8):1729-37

6. Sella A, Konichezky M, Flex D, Sulkes A, Baniel J. Low PSA metastatic androgen independent prostate cancer. Eur Urol 2000;38(3):250-4.

7. Sozen S, Uner A, Alkibany T. Small cell carcinoma of the prostate: Report of two cases. Turkish Journal of Cancer 2000;30(3):131-4.

8. Wang W, Epstein J I. Small cell carcinoma of the prostate: A morphologic and Immunohistochemical study of 95 cases. Am J Surg Pathol Jan 2008;32(1):65-71.

9. Wagner D G, Cheng L. Pathology of small cell prostate carcinoma. http://emedicine.medscape.com/article/1611899overview\#showall Erisim 01.03. 2012.

10. Senekjian EK, Weiser PA, Talerman A, Herbst AL. Vinblastine, cisplatin, cyclophosphamide, bleomycin, doxorubucin, and etoposide in the treatment of small cell carcinoma of the ovary. Cancer 1989;64(6):1183-7.

11. Orhan B, Yalcin S, Evrensel T, Yerci O, Manavoglu O. Succesfull treatment of cranial metastases of extrapulmonary small cell carcinoma with chemotherapy alone. Med Oncol 1998;15(1):669

12. Çoşkun HŞ, Er Ö, Altınbaş M, ve ark. Ekstrapulmoner küçük hücreli kanser: Tedavi ve prognoz. Türk Onkoloji Dergisi 2001;16(4):191-3. 